\title{
Kva er eigentleg målet i matematikken?
}

\author{
Hans Georg Schaathun og Jan Gunnar Moe ${ }^{\star}$, NTNU — Noregs Teknisk-Naturvitskaplege Universitet
}

SAMANDRAG: Denne artikkelen tek for seg iterativ evaluering, revisjon og design over to år, for eit emne i grunnleggjande matematikk. Me har lagt vekt på tett dialog med studentane, mellom anna gjennom improvisert quiz i forelesingane. I denne tette kontakten vart me overraska av to observasjonar. For det fyrste var hovudutfordringa for studentane ikkje dei grunnleggjande rekneferdigheitene som me trudde på førehand. For det andre vert vesentlege læringsmål i emneskildringa neglisjerte både av læreboka og på eksamen, og studentane har òg lært seg til å neglisjera dei.

Den andre observasjonen gjer at me stiller spørsmålet om kva som eigentleg er målet. Studentar som skal bruka matematikken i andre disiplinar treng kommunikasjons-, modellerings- og tankesettskompetanse, som ikkje tidlegare har vore vurderte ved eksamen. Skal matematikken vera nyttig, må desse måla løftast fram som naudsynte. Dei grunnleggjande ferdigheitsmåla som tradisjonelt vert prøvde på eksamen er aldri tilstrekkelege, og det er uklart i kva grad dei kan vera naudsynte.

\section{INNLEIING}

Høge stryktal i matematikk er ei utfordring kjend frå mange studium. Emne- og studieansvarlege landet over freistar stadig nye tiltak for å auka gjennomstrøyminga. Matematikken er prega av sterke tradisjonar og forventingar om kva studentane bør kunne. Nyare forsking på matematikkdidaktikk, t.d. om matematikkompetansar (Niss \& Højgaard, 2011), reiser likevel spørsmål om kva som er vesentleg i matematikkopplæringa. So langt, i høgare utdanning, har ikkje denne forskinga ført til anna enn spreidde og lokale endringar.

Forfattarane starta hausten 2017 eit arbeid for å fornya undervisinga i Grunnleggjande matematikk ${ }^{1}\left(7 \frac{1}{2}\right.$ studiepoeng) ved NTNU i Ålesund. Den opprinnelege tanken var at aktiv læring skulle gje betre utbyte, gjennom quiz, diskusjon og oppgåver i førelesingane. Responsen frå studentane avdekte derimot meir djuptgripande utfordringar, deriblant manglande samsvar (Biggs \& Tang, 2011) mellom læringsmål, undervising og eksamen. Dette vart starten på eit målretta arbeid for å designa eit nytt undervisingsopplegg basert på ein heilskapleg forståing av matematikken i kontekst.

Emneskildringa omfattar kompetansemål som å kunna

- «bruke matematikk til å kommunisere om økonomiske og samfunnsmessige sammenhenger»,

- «bruke matematikk til å formulere og analysere økonomiske og samfunnsmessige sammenhenger».

Desse måla føreset det som Niss og Højgaard (2011) kaller kommunikasjons-, tankesetts- og modelleringskompetanse. Niss og Højgaard identifiserer totalt åtte slike matematikkompetansar som går på tvers av prosedyreferdigheitene som skulematematikken ofte legg mest vekt på.

Når me ser tilbake på tidlegare sensur og undervising i dette og andre emne, ser me at slike formuleringar er vanlege i mange matematikkemne, samtidig som eksamen ikkje vurderer om utbytet er oppnådd. Røynslene frå emnet vårt viser at studentane veit svært godt kva som vert vurdert på eksamen. Det er

\footnotetext{
* Arbeidet vart fyrst presentert på MNT-konferansen 2019. Dette er ei utvida utgåve.

${ }^{1}$ Hans Georg Schaathun tok over emneansvaret i 2017. Jan Gunnar Moe var uavhengig observatør og diskusjonspartnar i 2017. I 2018 hadde han halvparten av undervisingstimane og haldt fram som diskusjonspartnar. Han var dessutan sentral då emnet vart oppretta i 2014 òg underviste det dei fyrste to åra.
} 
rekneferdigheitene som vert vurderte, og studentane er ikkje interesserte i å bruka tid på å tilegna seg andre matematikkompetansar, som ikkje vert vurderte på eksamen.

Denne artikkelen problematiserer måla for matematikkundervisinga med utgangspunkt $\mathrm{i}$ emneutviklinga som me har vore igjennom. Sjølv om arbeidet er avgrensa til eitt einskild emne, reknar me med at dei fleste innsiktene lèt seg generalisera til andre matematikkemne. So vidt me veit er innsikta som me presenterer ikkje tidlegare drøfta innanfor høgare utdanning. Mykje er tidlegare kjend frå grunnskulepedagogikken, men lite er direkte overførbart utan omfattande nytolking, og det er i denne tolkinga at vårt bidrag ligg.

Etter at me har presentert metodeverket vårt i neste avsnitt, vil me gå gjennom emnedesignet og observasjonane som er gjort (avsnitt 3). Tolkinga vår, med nye funn, er delt mellom mål i matematikkundervisinga (avsnitt 4) og utviklingsmetode (avsnitt 5). Me gjev eit kort literaturoversyn i avsnitt 6 før me konkluderer og vurderer vegen vidare $i$ avsluttinga.

\section{DESIGN- OG FORSKINGSMETODE}

Me ser på undervising som eit designproblem (jf. t.d. Collins, 1992). Der vitskapen søkjer å skildra eller forklara verda slik ho er, søkjer designfaget å skildra verda slik ho kan verta. Ein av dei mest siterte forfattarane i designmetode, Simon, 1996, formulerer det slik:

Everyone designs who devises courses of action aimed at changing existing situations into preferred ones.

I undervisinga handlar det om å utvikla undervisings- og læringsaktivitetar som skaper læring, som igjen tyder at studenten set seg i ein føretrukken situasjon, med auka kompetanse. Design av læremateriell eir éitt av tiltaka som legg grunnen for læringsaktivitetar.

Målet i studien har vore å utvikla eit best mogleg emne for studentane. Kvar læringsaktivitet er eit produkt både av læraren sin plan og av dei studentane som faktisk tek del. Utviklinga er difor eit resultat av kontinuerleg dialog med studentane, og løysingane vil ikkje alltid passa like godt til andre studentgrupper. Studien må difor vera idiografisk, og me går inn for ei hermeneutisk forståing ${ }^{2}$, i tråd med metodeverket i design og andre humanistiske fag, meir enn empirisk innsikt i poppersk forstand.

Utviklingsmetoden er iterativ, med kontinuerleg evaluering og validering basert på alle tilgjengelege datakjelder, inklusive

1. Dokumentstudiar; emneskildringar og eksamensoppgåver frå tidlegare år.

2. Referansegrupper med rundt fem studentar og møte tre gongar i semesteret.

3. Observatør i førelesingane fyrste år.

4. Korte evalueringsspørsmål gjennom quiz i førelesingane (Schaathun \& Gundersen, 2018).

5. Uformelle innspel frå studentane.

6. Eksamenssvar, samt svar på obligatoriske innleveringar.

7. Dagbok med fortløpande registrering av observasjonar, røynsler og idéar.

Hevner (2007) føreslår ein tresirkelprosess for programvareutvikling, og denne kan lett vidareførast til undervising som vist i figur 1. Kvar sirkel er ein hermeneutisk sirkel, der ein gradvis raffinerer designet ved vekselvis å fokusera på heilskapen og på delane.

- Den indre (design-)sirkelen ser på emnedesignet og vekselverknaden mellom overordna mål (heilskap) og einskilde læringsaktivitetar (delar).

- Relevanssirkelen ser på forholdet mellom emnet og faget (som delar) på den eine sida og på studentane og behova deira (som heilskap) på den andre.

\footnotetext{
${ }^{2}$ Hermeneutikk er læra om fortolking, opprinneleg forståing av klassiske og heilage tekster. Sidan er omgrepet utvida, og Wilhelm Dilthey såg hermeneutikken som eit metodeverk for åndsvitskapane. Gadamer, 1960 vert rekna som ein grunnleggjar av den moderne hermeneutikken, som me no kan sjå som ein teori for all forståing.
} 


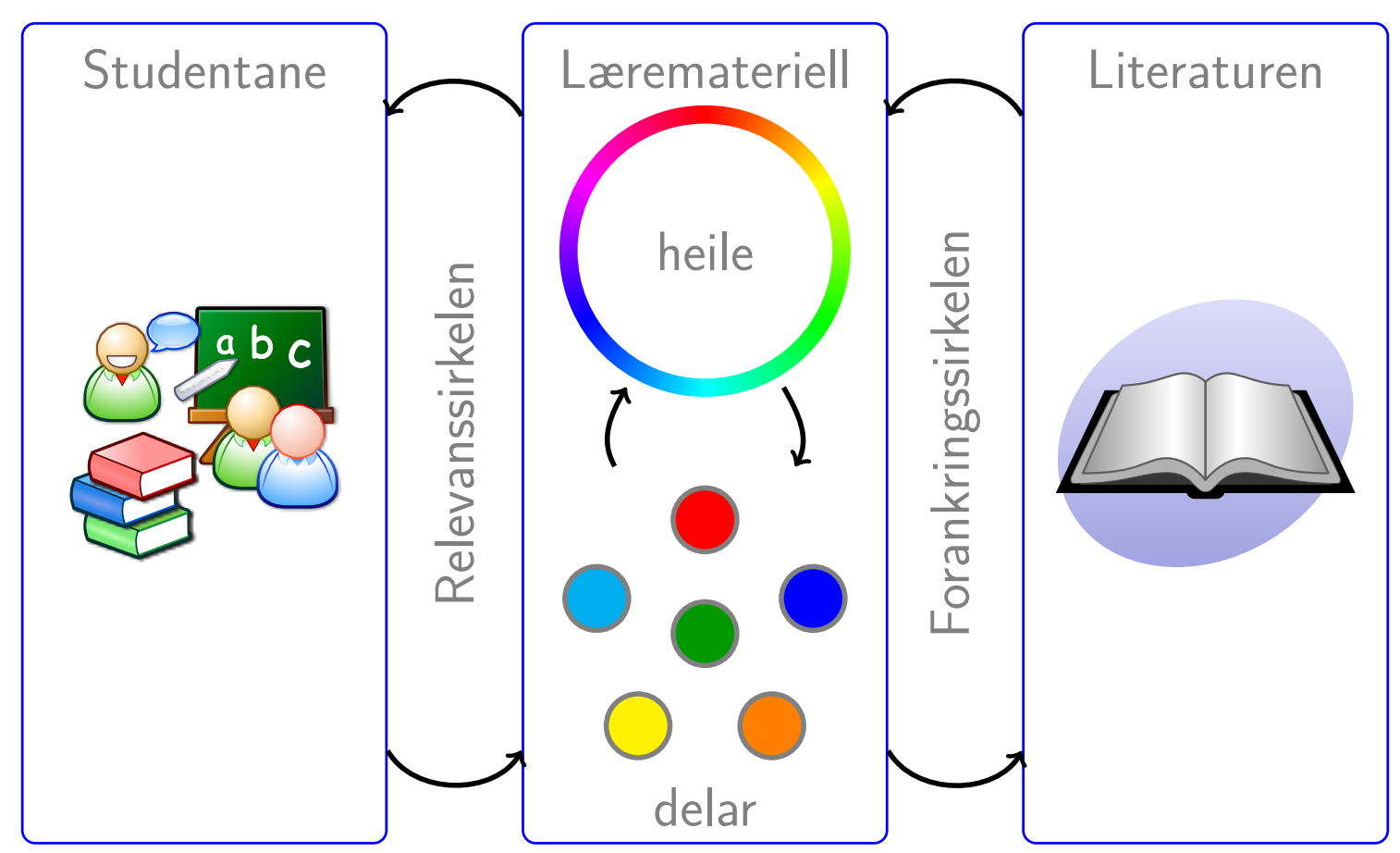

Fig. 1. Hevners tre-sirkel-modell omsituert til didaktikken.

- Forankringssirkelen (rigour cycle) ser på forholdet mellom emnet (del eller særtilfelle) og pedagogisk litteratur (heilskap og generalisering).

Utviklingsarbeidet vekslar då mellom dei tre sirklane for å evaluera og vidareutvikla emnet. Nokre resultat kan implementerast umiddelbart same semester, medan andre krev førebuing til fylgjande år. Både relevans- og forankringssirkelen validerer designet, og relevanssirkelen omfattar gjerne eit element av empirisk evaluering.

Særleg relevanssirkelen gjev oss stadig vekk overraskingar, som tving oss til å omdefinera problemet; det som Schön (1983) kallar reframing av problemet. Tradisjonelle empiriske vitskapsmetodar føreset veldefinerte problem med veldefinerte løysingskriterium, slik at ein veit kva empiriske data ein skal sanka inn og korleis ein skal vurdera dei. Schön (1983) peiker på at verkelege problem i røynda er kaotiske og unike. Dei passar ikkje inn i vitskaplege standardmodellar som kan løysast systematisk. Undervising er, som me skal koma tilbake til, eit slikt problem, og det krev at læraren er viljug til å reflektera over og revurdera sjølv dei mest innbarka førestillingane om kva som er essensen i faget og læringssituasjonane.

\section{EMNEDESIGN OG RØYNSLER}

Emnet i Grunnleggjande Matematikk er i all hovudsak basert på tradisjonelle førelesingar $3 \times 2 \mathrm{~h}$ i veka, og det var ein føresetnad for prosjektet at me ikkje skulle gjera radikale endringar i dette opplegget. Me har tidlegare argumentert for diskusjon som ein form for aktiv læring (Schaathun, 2015), og utgangspunktet vårt var at me ved hjelp av digitale quizverkty skulle overføra denne diskusjonsmetoden til klasser med over 70 studentar i auditoriet.

\subsection{Diskusjon som læringsaktivitet}

JazzQuiz er eit quizsystem til bruk i klasserommet, der læraren kan stilla spontane spørsmål i tillegg til planlagde spørsmål. Me utvikla JazzQuiz for å få ein tettare dialog med studentane, i sanntid, på førelesing 


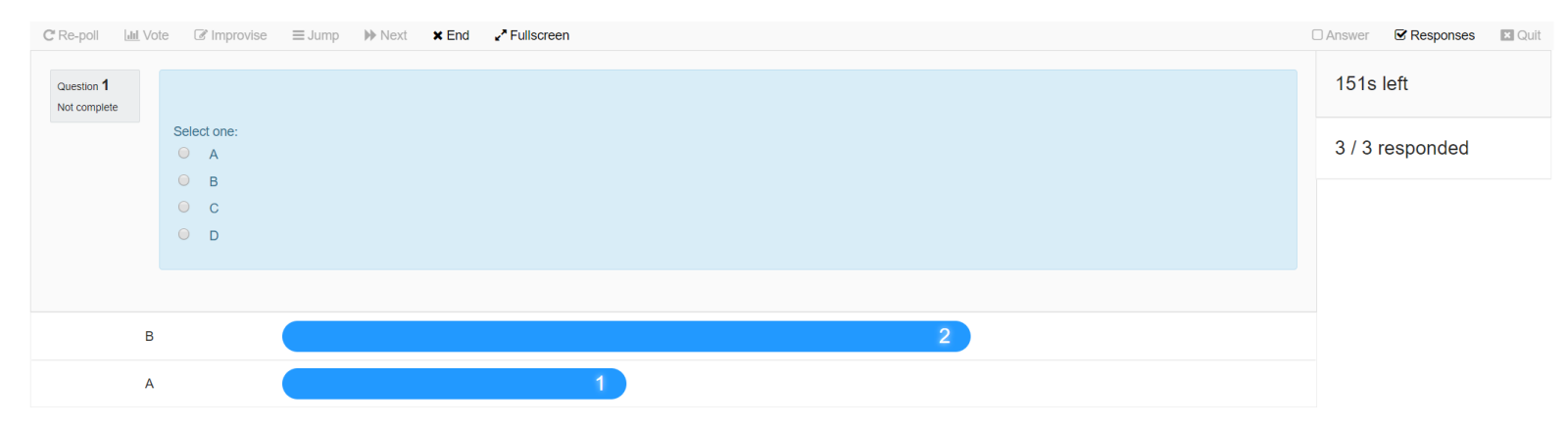

Fig. 2. Skjermbilete frå JazzQuiz.

(Schaathun \& Gundersen, 2018). For å få det til, må førelesaren stå fritt til å respondera på svar og spørsmål frå studentane, ikkje berre med ekstra forklaringar i førelesingsstil, men òg med nye spørsmål i diskusjonen. Me har brukt JazzQuiz både til faglege spørsmål, evalueringsspørsmål (t.d. går det for fort/for sakte?) og til spørsmål frå studentane (skrivne som fritekstsvar). Svara frå studentane vert vist som stolpediagram (Figur 2), som er ideelt der identiske svar går igjen.

I ettertid ser me at JazzQuiz ikkje berre får studentane med i kognitiv aktivitet, men òg gjev læraren betre kontakt med og forståing for studentane. Me oppnådde ein dialog og ei openheit som prega heile klassa gjennom semesteret. Mange studentar kom med faglege og metafaglege innspel både oppmoda og uoppmoda utanom dei organiserte diskusjonane, i langt større omfang enn me er vane med. Dette gav oss ei unik innsikt $\mathrm{i}$ korleis studentane oppfattar og arbeider med ulike formar for matematiske problem.

Dette leier oss til å sjå undervising som disiplinert og kreativ improvisasjon (Sawyer, 2004). Førelesing etter manuskript er for oss øydeleggjande, fordi me er avhengige av å møta studenten der han eller ho er, for at me «i Sandhed skal lykkes [...] at føre et Menneske hen til et bestemt Sted», for å bruka Kierkegaards velkjende ord. Når ein på dette viset tek studenten på alvor, som ein aktiv deltakar i si eiga læringsprosess, fylgjer det at førelesinga nødvendigvis må vera eit produkt av møtet med studenten og ikkje læraren sitt eige verk. Dermed fylgjer me Karlsen (2006), som problematiserer førestillinga om at improvisasjon er ein «form for mindreverdige nødløsninger i undervisningsmessige tvangssituasjoner - hvor alt har gått på tverke».

I løpet av emnet gjorde me to viktige og overraskande observasjonar, som me utdjupar i neste avsnitt:

1. Hovudutfordringane for mange studentar var ikkje dei grunnleggjande ferdigheitene som me trudde på førehand.

2. Vesentlege læringsmål vert neglisjerte av både læreboka og eksamen, og studentane ser heller ikkje slike mål som naturlege steg på vegen mot mål som vert eksaminerte.

\subsection{Observasjonar 2017}

Emnet har tradisjonelt byrja med 3-4 veker repetisjon av ungdomsskulepensum som t.d. grunnleggjande brøkrekning og multiplikasjon av algebraiske uttrykk, som røynde førelesarar veit at denne studentgruppa slit med. Diagnostiske øvingar i JazzQuiz viste derimot at fleirtalet kunne løysa dei fleste av desse oppgåvene. Problema oppstod når fleire grunnleggjande element vart kombinerte, t.d. brøk med algebraiske uttrykk. Det er fyrst i ettertid at me kan sjå kor stor skilnad det er på å kunna utføra ulike enkle prosedyre kvar for seg, og å kunna bruka dei same prosedyrane i ein samansett prosedyre.

Liknande observasjonar går igjen. Studentane viser at dei kan grunnleggjande ferdigheiter i enkle øvingar, men misser dei same ferdigheitene når dei treng dei i praksis. I diskusjonar med bedriftsøkonomimiljøet for fleire år tilbake, var der éin ting studentane verkeleg trong å læra i matematikken: lineære likningar med éin og to ukjende. Det kunne dei på eksamen i matematikk, men når dei seinare møtte det i bedriftøkonomi, kunne dei det ikkje. 
Oppgåve 3 (24\%)

Drøft og skissér funksjonen

$$
f(x)=-x^{3}+2 x^{2}-x .
$$

Svar på fylgjande spørsmål, og markér svaret både i skissa og i teksta.

1. Kva ekstremalpunkt (maksimum og minimum) har funksjonen? Bestem $x$ - og $y$-verdiane til ekstremalpunkta.

2. Kva nullpunkt har funksjonen?

3. For kva $x$-verdiar er funksjonen stigande?

4. For kva $x$-verdiar er funksjonen positiv? Dvs. $f(x)>0$.

5. Finn vendepunktet til $f(x)$. Vis både $x-$ og $y$-verdien.

6. Kva skjer med funksjonsverdien $f(x)$ når $x \rightarrow \infty$ ?

Tabell 1. Oppgåve frå eksamen 7. desember 2017.

\section{Oppgåve 6 (15\%)}

Ei anna bedrift har kostnadsfunksjonen

$$
K(x)=x^{2}+10 x+30 .
$$

1. Finn eit uttrykk for grensekostnaden $K^{\prime}(x)$ ?

2. Finn eit uttrykk for gjennomsnittskostnaden $A(x)$ når bedrifta produserer $x$ dingsar?

Sjå no på tilfellet der bedrifta leverer $x=10$ dingsar.

3. Finn gjennomsnittskostnaden for $x=10$

4. Finn grensekostnaden for $x=10$

5. Kva må utsalsprisen vera for at bedriften skal gå med overskudd?

6. Kva må utsalsprisen vera for at det skal løna seg å auka produksjonen?

Tabell 2. Oppgåve frå eksamen 7. desember 2017.

For å unngå å pugga ferdigheitene utan kontekst, la me stor vekt på praktiske problem i undervisinga. Gjennom diskusjon freista me saman å forstå problemet og finna matematiske modellar og løysingar. Ein replikk frå auditoriet illustrerer situasjonen:

\section{Kan du ikkje berre gje oss ein formel, so me kan byrja å forstå?}

Liknande reaksjonar gjekk igjen, t.d. korleis ein skal føra ein spesifikk løysingstype på eksamen. Studentane er vane med å kopiera løysingsskjema for spesifikke oppgåvetypar, Dei er ikkje vane med å tolka oppgåvene for å forstå dei ut frå ein praktisk samanheng eller uttrykkja eigne tankar.

Eksamen stadfester dette inntrykket. Me laga eit eksamenssett stort sett med typiske spørsmål frå tidlegare eksamenssett, men på to oppgåver la me inn variasjonar.

1. Me bad studentane «drøfta og skissera» ein gjeven (tredjegrads)funksjon (sjå tabell 1). Som ledd i drøftinga, skulle dei svara på nokre spesifikke spørsmål, som har vore typiske på tidlegare eksamensoppgåver. Kravet om skisse var nytt, men hadde vore diskutert på førelesing. Det som er interessant er at svært mange studentar kunne svara på dei konkrete detaljspørsmåla, utan å kunna setja svara saman i ein heilskap i form av ei skisse. Mange freista ikkje å teikna i det heile, og mange teikna noko som ikkje var konsistent med utrekningane.

2. Saman med spørsmål om grensekostnaden (dvs. den deriverte av ein kostnadsfunksjon) spurde me kva må prisen vera for at det skal løna seg å auka produksjonen? (Sjå tabell 2.) Fleirtalet av studentane hadde ingen problem med å rekna ut grensekostnaden, men blant 135 studentar var der 2-3 som såg samanhengen mellom grensekostnad, pris og inntening ved produksjonsauke. Tilsvarande spurde me, 
etter at studentane hadde rekna ut gjennomsnittskostnaden (per eining), om kva prisen må vera for å gå med overskot. Heller ikkje her klarte meir enn 2-3 studentar å svara på spørsmålet.

Båe desse oppgåvene viser tydeleg at mange studentar som kan rekna, ikkje kan setja sine eigne svar i ein meiningsfull samanheng. Emnet feilar når studentane skal læra å bruka matematikken i ein yrkessamanheng.

\subsection{Nytt læringsmateriell 2018}

Basert på røynslene frå 2017 vart eit nytt oppgåvehefte ${ }^{3}$ utvikla til undervisinga 2018. Dette vart bygd som parra døme (Clark mfl., 2005), der studentane får par med eitt gjenomarbeidd døme og éi øvingsoppgåve utan fasit. Dømet har løysingsforslag som skal vera tilstrekkeleg til å læra ny teori og nye metodar utan forutgåande forklaring. Slik skulle det vera mulig å fylgja kurset utan å lesa læreboka. Øvingsoppgåvene skal vera sopass like dømet, at det vert overkommeleg å løysa oppgåva for alle.

I nokre tilfelle vart fleire enn éi øvingsoppgåve lagde til, dels for å gje mengdetrening, og dels for å gje breiare døme der studentane òg vert trente i overføring av kunnskap. Eit anna prinsipp frå Clark mfl. (2005), som vert brukt berre i liten grad, er løysingsforslag med fading, dvs. seriar med oppgåver med ufullstendige løysingsforslag der studentane må fylla inn meir og meir sjølv.

Det store fleirtalet av oppgåver var tekstoppgåver, der det er venta at studentane tolkar oppgåva, matematiserer, løyser, og tolkar den abstrakte løysinga tilbake i oppgåveteksta. Særleg i kapittelet om renterekning og finansmatematikk var det mogleg å finna gode og relevante døme.

Målet med det nye oppgåveheftet var å trena studentane primært i matematisering, dvs. bruka matematikk for å tolka, forstå og løysa problem frå røynda. Rekneferdigheiter, som allikevel kan gjerast maskinelt, vart tillagd mindre vekt.

I tillegg til nye oppgåver innførde me nye arbeidskrav med medstudentvurdering, der studentane skulle levera fyrst eiga løysing, so medstudentvurdering, og til slutt revidert løysing med refleksjon. Ved den andre innleveringa vart dette forenkla til at studentane skulle løysa oppgåvene kvar for seg, og so møtest i grupper for å vurdera kvarandre munnleg. Alt vart levert inn samla til slutt.

\subsection{Observasjonar 2018}

Det nye oppgåveheftet vart godt motteke. Fleire studentar har fortalt, spontant og på eige initiativ, at det har gjort matematikken langt meir meiningsfull og dei har fått eit nytt syn på kva matematikk er. På dei fleste andre punkt spriker tilbakemeldingane frå studentane mykje.

Det kjem fram i referansegruppa at $3 \times 2 \mathrm{~h}$ førelesing er vesentleg meir enn andre emne på studiet. Dei seier òg at det er positivt og uvanleg at førelesaren er til stades på rekneøvinga. Trass i dette er der få studentar som møter på øving. Midt i semesteret er der ofte rundt 70 på førelesing og 10-15 på øving. Me prata med fleire studentar som midt i semesteret knapt hadde byrja å arbeida med oppgåver. Emnet er altso uvanleg tidkrevjande for førelesar, og samstundes tek studentane i liten grad del i dei studentaktive øktene.

Mange av dei same utfordringane som me såg i 2017 held fram i 2018. Svært få studentar tolkar oppgåvene. I staden går dei direkte til å setja tal inn i ein formel, og litt for ofte feil formel. T.d. når dei skal rekna på annuitetar i finansmatematikken, bruker dei gjerne same formel uansett om dei skal finna saldoen like etter siste innskot eller saldoen eitt år seinare, når siste innskot har fått renter for eitt år. Dvs. at dei ikkje

${ }^{3}$ Dette ligg ope på http://www.hg.schaathun.net/math/finance/ (finansmatematikk) og http://www.hg.schaathun.net/math/ cost/ (funksjonar). 
kan skilja mellom dei to rekkjene

$$
\sum_{i=0}^{t-1} x \cdot(1+r)^{i} \quad \text { og } \quad \sum_{i=1}^{t} x \cdot(1+r)^{i} .
$$

Av dei tre hovudtemaa var det drøfting og skissering av funksjon som gav studentane størst utfordring på eksamen. Som i 2017 var der få studentar som evna å teikna ei skisse konsistent med utrekningane.

Svært få studentar lærer seg å validera eigne resonnement eller argumentera for løysingane. Dette gjer seg utslag i krav om fasit. Det er ein velkjend observasjon at studentane, i matematikk i langt større grad enn $i$ andre fag, manglar ei kjensle for om løysinga deira er korrekt eller ikkje. For mange er det berre fasit og tilbakemelding frå læraren som bidreg til sjølvtillit (jf. Kloosterman \& Cougan, 1994). Oppgåver utan fasit er klart den mest kontroversielle sida ved opplegget, sjølv om referansegruppa ser argumentasjonen vår. Det er framleis eit ope spørsmål, korleis me kan utvikla metakognisjon og læra studentane å validera eigne svar. Mangelen på fasit hjelper til å fokusera på utfordringa, men det er uvisst i kva grad det hjelper til å overvinna ho.

Der finst både studentar som ynskjer høgare framdrift og andre som vil ha lågare tempo. Det ser me både kontinuerleg på aktiviteten i JazzQuiz og på direkte tilbakemeldingar. Det er i og for seg inga overrasking at der er stort sprik i forkunnskapar. Ein student ynskjer seg ein mellomting mellom dette emnet og det ordinære matematikkemnet for siviløkonomstudiet.

Eit par studentar er kritiske til fokuset på gjennomarbeidde døme, og bed tydeleg om ei meir tradisjonell, deduktiv tilnærming.

Foreleserne bør forklare tema og vise formler vi bør huske og deretter gå gjennom oppgavene for eksempel fra heftet eller boka. Det hadde vært mye enklere for oss å forstå det de nettopp gikk gjennom og da hadde vi husket ting bedre.

Opplegget vårt byggjer på den induktive metoden, som Colburn (1822) ofte får æra for. Den deduktive metoden, som starter med generelle forklaringar som so vert brukt på spesialtilfelle, kan nok som studenten seier, vera raskare. Hendrix (1947) har derimot vist at studentar som sjølv generaliserer frå døme, altso arbeider induktivt, opparbeider ein taus kunnskap (j.f. Polanyi, 1983) som gjer dei betre i stand til å overføra kunnskap.

Skriftleg medstudentvurdering fekk mykje kritikk, og innleverte arbeid viste òg at studentane i liten grad evna å bruka tilbakemeldingane konstruktivt. Likevel var der nokre positive opplevingar, t.d. at det var nyttig å sjå korleis andre løyste oppgåvene. Somme grupper møtte kvarandre for å drøfta tilbakemeldingane og oppgåvene, og dei hadde langt meir utbyte av prosessen enn dei som berre gjorde arbeidet skriftleg. Dette var bakgrunnen for det forenkla opplegget ved andre arbeidskrav, men denne prosessen framstod òg som unødig komplisert og langdryg. I 2019 vert dette ytterlegare forenkla til gruppearbeid, der studentane individuelt leverer løysingar og refleksjon i etterkant, men det må me koma tilbake til i ein seinare artikkel.

Ved sensuren auka andelen C frå 15,4\% i 2017 til 20,3\% i 2018 og andelen F sank frå 42,6\% til 35,5\% (rundt 135-140 eksaminandar kvart år). Ogso D hadde auke frå 14,7\% til 17,4\%; andre endringar var under eitt prosentpoeng. Eksamensoppgåvene var stort sett dei same i genre og vamskegrad, men noko av forbetringa kan ein forklara ved me tydelegare formidla kva oppgåvegenrar dei skulle forventa og kva me forventar til ein $\mathrm{C}$.

\section{MÅL OG MEINING}

Me har påvist ein konflikt mellom to fundamentalt ulike tilnærmingar til å forstå matematikken. Den eine startar med konkrete problem og tek sikte på å forstå røynda rundt seg. Matematiske konsept og teknikkar vert innførde som hjelpemiddel for betre å drøfta og forstå problemet. Den andre, tradisjonelle, 
tilnærminga tek utgangspunkt i abstrakte, matematiske konsept og føreset at studentane allereie forstår dei, og bruker dei til å forklara nye konsept. Anvendingane og konkrete døme kan vera eit hjelpemiddel, men målet er abstrakt forståing.

Når ein skal bruka matematikken for å forstå, analysera eller kommunisera om økonomiske og samfunnsfaglege problemstillingar, går ein gjennom fleire steg som krev ulike matematikkompetansar (t.d. Niss \& Højgaard, 2011). Det fyrste er tankesettskompetansen, at ein kjenner att matematiske samanhengar i røynda. Deretter treng ein modelleringskompetansen for å omsetja eit konkret problem i ein matematisk modell. Symbolmanipulering er ofte naudsynt for å omforma den fyrste formuleringa til ein som er enklare å løysa. Fyrst når alt dette er gjort, står ein med eit ferdig abstrakt, matematisk problem der rekneferdigheitene kjem til nytte, før ein til slutt skal tolka svaret tilbake i det konkrete problemet, og ikkje minst overtyda andre om at ein har resonnert fornuftig (kommunikasjonskompetanse).

I heile denne prosessen er det rekneferdigheitene som er enklast å automatisera og gjera maskinelt. Paradokset er at ein typisk matematikkeksamen berre prøver studenten i desse rekneferdigheitene, som dei sannsynlegvis aldri skal bruka igjen, fordi datamaskiner gjer jobben betre. Dei andre stega i prosessen krev meir fagleg skjønn, og dermed kyndige menneske som kan tolka problemet og omsetja det til maskinløysbar form. Dette vert derimot studentane sjelden vurdert på.

At svært mange studentar slit med å tilegna seg grunnleggjande ferdigheiter i aritmetikk og algebra, er velkjent. Det som me har lett for å gløyma når me planlegg og underviser matematikkurs, er at ogso mange studentar som meistrar rekneferdigheitene på abstrakte eksamensproblem, ikkje klarer å bruka ferdigheitene i ein meiningsfull samanheng. Det er relativt enkelt å programmera datamaskiner til å løysa abstrakte problem, og dermed dei fleste eksamensoppgåver på fyrsteårsmatematikken på universiteta. Det vil seia at ikkje ein gong studentar som får toppkarakter har vist at dei kan noko som helst som ikkje robotar gjer minst like godt.

Det som me har sett i Grunnleggjande Matematikk, er at matematikken, for studentane, heilt ut er forma som ein akademisk øving. Sjølv om mange spør om kva dei kan bruka matematikken til i det verkelege livet, ynskjer dei seg typisk raske forklaringar tilpassa eksamenskonteksten. Dei puggar løysingsformular som skal tilfredsstilla sensorar som kan matematikken til fingerspissane. Tanken på å bruka matematikken for å kommunisera med andre som gjerne kan mindre matematikk enn dei sjølve, er framand.

Som matematikkundervisarar har me kunne sitja stille i båten under heile bølgja med aktiv laering dei siste tiåra, vel vitande om at me alltid har lagt stor vekt på aktiv læring i form av rekneøvingar der studenten løyser oppgåver med meir eller mindre aktiv rettleiing. Dette er so rotfesta at det til og med har definert kva matematikk er for studentane.

Oppgåva for ein yrkesutøvar vil vera å bruka matematikken til å forstå - finna meining i - eit problem frå røynda. Løysinga er ikkje matematisk, men matematikken er ein reiskap for å finna ei løysing på eit problem i røynda. Yrkesutøvaren kan aldri slå seg til ro med at løysinga er funne, utan at han kan overtyda kollegaar, som gjerne kan mindre matematikk enn han sjølv, om at løysinga er riktig og god i konteksta.

Lat oss presisera at nokre studentar kan gjera det bra med matematikkopplæringa slik som ho er i dag. Det er dei studentane som lærer stoffet so godt at dei kan henta det fram utan strev, og dermed bruka det $i$ andre fag, ofte fleire år seinare. Saka vår er den store gruppa som ikkje lukkest so godt i skulematematikken, men som like fullt kan verta habile yrkesutøvarar. Kan dei òg få del i dette kraftfulle verktyet som me kaller matematikk?

Dette problematiserer skiljet som me dreg mellom å gjera og å forstå i matematikken. Det er ofte dei abstrakte rekneoppgåvene som definerer «å gjera», medan forståing handlar om å kunna forklar kvifor ein har gjort som ein har gjort. I eit profesjonsperspektiv derimot, handlar «å gjera matematikk» om å bruka matematikken som reiskap til forståing og kommunikasjon.

Holm (2012, s. 44) skil mellom pugg og forståing, heller enn mellom «å gjera» og «å forstå»: 
Prosedyremessige kunnskaper kan læres både i situasjoner der forståelse blir satt i fokus, og som mekanisk pugg, men vil da fungere som isolerte kunnskapsenheter.

Når studentane kan finna null- og ekstremalpunkt, men ikkje teikna ein konsistent skisse, er det truleg fordi dei har pugga løysingsteknikkane som isolerte kunnskapseiningar, og ikkje som lekk i å forstå formen på ein funksjon. Røynslene våre stadfester utsegna frå Marit Holm. Studentana lærer seg rekneferdigheitene, men dei er uavhengige av all annan kunnskap, og dei fleste studentane klarer ikkje å bruka dei i ein nyttig samanheng. Tidlegare har me ofte utelate kontekstualisering frå matematikkundervisinga fordi me har tenkt på det som trivielt; det ser me no har vore ein feil.

Skiljet mellom pugg og forståing er meir presist enn skiljet mellom å gjera og å forstå, fordi rekneferdigheiten, strengt algoritmiske, kan puggast, av same grunn som dei er enkle å robotisera. Å gjera matematikk i ein profesjonskontekst krev derimot ein forståing for einskildtinga (jf. Schön (1983) og Aristoteles (1999, bok 6)), der løysinga må tilpassast kvart einskild fall. Då rekk det ikkje med pugg.

Alternativet til pugg har vore nemnd som forståing, men det er slett ikkje sikkert at me har ei sams forståing av kva forståing eigentleg er. Me har allereie brukt «forståing» på to måtar. Den eine kjem til uttrykk når studenten kan forklara kvifor ein puggbar løysing eller løysingsteknikk er korrekt. Den andre er forståinga for enkeltting, som let yrkesutøvaren skapa eit abstrakt og generelt løysbart matematisk problem frå eit spesielt og konkret problem i røynda. Dette er sopass vidt ulike oppgåver at der ikkje er nokon sterke grunnar til å tru at den same forståinga dekkjer båe oppgåvene. So har ogso Kerdeman (1998) peikt på eit avvik mellom ordbruken i hermeneutikk og i epistemologi.

Gadamer, 1960, som vert rekna som grunnleggjar av den moderne hermeneutikken, legg vekt på levde røynsler som utgangspunkt for læring. I teorien hans om hermeneutikk kjem all læring og forståing frå spenninga mellom det kjende og trygge på den eine sida og det nye og framande på den andre. Me forstår det nye gjennom det kjende, men her er det levde røynsler som utgjer det kjende og pugga prosedyrar har liten verdi. Dersom me tek utgangspunkt i problem frå røynda, som studenten kan leva seg inn i, kan me òg gjera det mogleg å leva seg inn i matematikken, som ein veg til å forstå, forklara eller fortelja om dei levde røynslene.

For nokre studentar, som har lært matematikken svært godt i tidlegare skulegang, kan sjølv abstrakt forståing vera det kjende og trygge ankerpunktet som gjer det mogleg å læra meir matematikk. Det er derimot ikkje nok å kunna litt matematikk, ein skal tenkja matematisk og kjenna seg heime i matematikken, for å bruka det som grunnlag for ny innsikt. Det er difor det står skrive,

For den som har, han skal få og det i overflod; men den som ikkje har, skal missa jamvel det han har. Difor talar eg til dei i likningar. For om dei ser, så ser dei ikkje; og om dei høyrer, så høyrer dei ikkje og skjønar ikkje.

Mat. 13.12-13

For at studenten skal få noko nytt, må me altso finna ut kva han allereie har og byggja på det.

Det er ingen god strategi å la matematikarane undervisa matematikk i abstrakt form, og henvisa anvendingane til seinare emne i andre fag. Det er i dei andre faga at studentane lever, og forståinga av matematikk kjem gjennom dei levde faga. Når matematikkundervisinga byggjer på matematiske forkunnskapar aleine, kastar me studentane ut i ei verd der dei er framande, utan levde røynsler som utgangspunkt for læring. Det er betre å føra matematikken inn i ei verd der studentane kjenner seg heime.

Når studentane innimellom spør, «kva kan me bruka dette til i det verkelege livet?» kan me tolka det både som leit etter motivasjon og som leit etter levde røynsler som utgangspunkt for forståing. Kan henda er det to sider av same sak. Det verkelege livet er studenten si eiga fortid og framtid slik som han sjølv opplever dei. Motivasjonen er ei førestilling om ei (mogleg) framtid som ein lever seg inn i som eit ynskje eller ein draum.

Motivasjon er ein del av studenten sine levde røynsler, og som Sotto, 2007 òg seier, ikkje noko som undervisarane kan skapa. Det beste ein kan håpa på som undervisar er ikkje å øydeleggja motivasjonen. Studentane er i utgangpunktet motiverte, anten det er til å forstå verda, universet og allting, eller til 
ein høgt gasjert leiarstilling i industrien. Det er difor dei startar på studiet. Motivasjonen går tapt når undervisinga ikkje tener formålet. Me kan ikkje gjera matematikken interessant for studentane, me må undervisa matematikk som er interessant.

Det er då eit paradoks at mange av studentane våre ikkje var motiverte for å arbeida med problem frå røynda, sjølv om dei var tydeleg relevante og vesentlege for vidare studiar. For dei skulle matematikkemnet vera ein studie i abstrakt prosedyrekunnskap utan å trengja å forstå røynda i det heile. Oppgåver som fordra matematisering av praktiske problem skar mot forventingane som studentane hadde til emnet, og det lét seg ikkje gjera i ei handvending å snu desse forventingane. Dette er ei utfordring, men me kan ana ei viss forbetring frå 2017 til 2018, ettersom me no kan visa til eit tidlegare eksamenssett som legg litt vekt på forståing av heilskap og praktisk kontekst.

\section{NY METODEINNSIKT}

Gjennom revisjonsprosessen i Grunnleggjande Matematikk har me mange gongar vorte overraska og tvungne til å revidera, ikkje berre undervisingsmetodane, men òg synet vårt på matematikk, på læring og på sjølve utviklingsprosessen. Det er verd å reflektera over denne utviklingsprosessen og -metoden, som har mogleggjort overraskingane som har leidd til ny innsikt. Sjølv om dette ikkje er ny metodekunnskap i ein absolutt forstand, er det moglegvis nytt innanfor pedagogikk og didaktikk. Innanfor design er det helst velkjent.

Særleg to observasjonar frå utviklingsprosessen peiker seg ut. For det fyrste, stadig reformulering av målet, og den direkte og uformelle kontakten med studentane.

Som nemnd starta me prosjektet med ein føresetnad om kva studentane sleit med, nemleg grunnleggjande rekneferdigheiter. Basert på føresetnaden hadde me ein plan for læringsaktivitetar for å opparbeide resonneringsevna rundt enkle problem. Spørsmål i JazzQuiz viste derimot at nesten ingen av studentane strevde på dette nivået. Derimot auka utfordringane svært kjapt når to teknikkar skulle kombinerast.

Etter denne oppdaginga måtte me altso brått omformulera problemet til å læra å resonnera rundt samanensette problem, og ikkje på einskilde ferdigheiter. Hensikta med JazzQuiz endra seg òg. Sjølv om den opprinnelege hensikta med å aktivisera studentane stadig var relevant, vart det viktigare å bruka JazzQuiz til å skaffa kontinuerleg oppdatert informasjon om kva studentane forstår og kva som er vanskeleg. Med den spontaniteten som JazzQuiz tillet var det òg mulig å tilpassa opplegget, og køyre nye diagnostiske testar utan å spilla tid, for å validera tilpassingane.

Liknande episodar har der vore mange av i løpet av prosessen, men ingen gjorde like stort inntrykk som den fyrste.

Det var fyrstehandsrøynsler som leidde oss inn i denne utviklingsmetodikken, men me kan i ettertid sjå at han er velkjend innanfor design. Norman (2013) peiker på at den største og viktigaste oppgåva er å finna rett spørsmål. Profesjonsutøvarar (og som undervisarar er det det me er) er avhengige av å sjå på kvart problem som eit unikt fall (Schön, 1983), og når dei testar løysingar, finn dei ofte at problemforståinga deira er feil. Dei må omformulera, reframe, problemet. I undervisingssamenhengen vår tyder det at kvar studentgruppe er unik; dei har ulik bakgrunn og tilnærming til studiet. Når me går inn i ein direkte dialog, og ser kva studentane forstår og kva dei slit med tidleg i semesteret, er det inga overrasking at me vert tvungne til å reframe problemet. Maher og Tang (2003) går eit steg vidare og taler om samevolusjon (co-evolution) av problem og løysing. Ikkje berre løysinga må optimaliserast, men ein må optimalisera problem(forståinga) òg. Det er dét me har sett i vår designprosess, at røynslene med kvar ny løysing har leidd til ei ny forståing av sjølve problemet.

Simon (1996) set dette i samanheng med det som han kaller bounded rationality, dvs. avgrensa minnekapasitet gjer det uråd ta omsyn til alle aktuelle omstende når me skal finna optimale løysingar. Det er kanskje ikkje mogleg å leggja ein undervisingplan for eit heilt semester. Han ser på alle utviklingsproses- 
sar som evolusjonære system, der val av løysing ikkje er bestemt aleine ut frå kva som er gode løysingar, men like mykje ut frå utgangspunktet som ein har. Ein kan ikkje utan vidare hoppa til ei betre løysing som ein ser. Svært ofte må ein via ei rekkje mellomstadium. Dette har me òg sett i emneundervisinga. Me kan ikkje utan vidare flytta fokus frå rekneferdighetar til modellering, fordi historia frå tidlegare skulegang og gamle eksamensoppgåver er so sterk og førande for korleis studentane tenkjer.

Det er ikkje rom i denne artikkelen for meir enn å skrapa i overflaten på denne omfattande literaturen i designmetode. Avslutningsvis skal me berre peika på den viktigaste føresetnaden for å bruka ein slik evolusjonsmessig utviklingsmetode, nemleg at me møter studentane der dei er. Det er berre gjennom det opne møtet, med ein genuin interesse for korleis studentane møter faget, at me kan forstå kvar me er i evolusjonsprosessen, og ingen veg fører til målet dersom han er planlagd frå eit anna startpunkt. Samstundes må undervisingsplanen vera sopass fleksibel, at ein kan lata omsynet til studentane vega tyngre enn omsynet til pensum og plan, i alle fall mykje av tida.

\section{LIKNANDE ARBEID I LITERATUREN}

Utfordringane med å undervisa matematikk er kompliserte. Dei mange forfattarane som har skrive om problemet, har fokusert på vidt forskjellige sider ved saka. Ein fullstendig literaturstudie ville gå langt utover rammane, so det beste me kan få til er nokre døme.

Selden, Selden og Hauk har gjennom fleire arbeid vist at studentane berre sakte utviklar evnene til å løysa anna enn rutineproblem (sjå Selden mfl., 2000, og referansane der). Dei lot studentane ta ein todelt test, med rutinemessige og ikkje rutinemessige oppgåver i dei to delane. Slik kunne dei kontrollera om studentane mangla naudsynte matematiske teknikkar, eller om dei berre ikkje klarte å overføra kunnskapen til mindre rutinemessige oppgåver. Dei fokuserte på studentar med middels gode og gode karakterar, og til dels studentar som gjekk vidare med matematikk. Dei ikkje rutinemessige problema som dei studerte var òg abstrakte matematiske problem.

Yoshinobu og Jones (2012) har peikt på ei rekkje vanlege misoppfattingar om kva matematikk er. Det er vanleg å tru at matematikkoppgåver skal løysast kjapt med velkjende teknikkar, at ein aldri skal gjera feil i matematikken og at det er tilstrekkeleg å pugga formlar. Yoshinobu og Jones argumenterer for at tradisjonell matematikkundervising ofte byggjer opp under desse misoppfattingane, ved å lessa på med stoff utan å gje studentane tid til å tenkja, og til å gjera feil. Ei mogleg løysing er inquiry-based learning (IBL).

At det er viktig å kunna gjera feil, vert òg drege fram av Boaler (2015). Ho er kanskje den som er mest kjend for å fremja IBL i matematikkundervisinga. Boaler (1998) samanlikna prestasjonane på to skuler med ulike undervisingsopplegg. Elevane som fekk tradisjonell matematikkundervising svarte vesentleg betre på reine prosedyrespørsmål enn IBL-elevane, men vesentleg dårlegare på konseptuelle spørsmål, som gjerne er rekna som vanskelegare. For IBL-elevane var der berre marginal skilnad mellom prestasjonane på prosedyrespørsmål og konseptuelle spørsmål.

Innanfor økonomisk/administrative fag er IBL prøvd ut m.a. av Piercey og Militzer (2017), der IBLkurset drastisk har redusert fråfall blant studentane på alle prestasjonsnivå. Klassene ser derimot ut til å vera små; dei nemner $n=57$, totalt over to årskull. Dei drøftar dei mange ulike utfordringane ein må venta seg når ein implementerer IBL. Eit anna arbeid innanfor økonomisk/administrative fag er Green og Emerson (2008), som brukte autentiske problem servert i form av profesjonelle memos. Ogso her var klassene små, med 20-25 studentar.

Gruppearbeid som læringsarena i matematikk har vore studert her til lands, m.a. av Krogstie mfl. (2018) på dataingeniørstudiet og Foldnes (2016) på BI. Krogstie et al. bygde på metodeverket team based learning (TBL), sjølv om dei avvek noko i oppgåveform. Foldnes gjorde ein kontrollert, randomisert studie der han samanlikna tradisjonelle førelesingar med omvendt klasserom. I forstudien, med individuelt arbeid i rekneøvingane, fann han ingen statistisk signifikant endring. Då han i hovudstudien brukte plenumsøktene 
til grupparbeid, fann han derimot ein signifikant forbetring i prestasjonane i den klassa som fekk omvendt klasserom.

Ein kontroversiell studie av Kaminski mfl. (2008) argumenterte for at studentane er betre tente med å studera matematikk ut frå ein einskild abstrakt representasjon enn fleire konkrete representasjonar. De Bock mfl. (2011) problematiserte dette biletet. Studentane som lærer i en abstrakt kontekst, lærer å overføra kunnskapen til andre abstrakte problem. Studentar som lærer i konkrete kontekstar lærer overføring til andre konkrete kontekstar.

Øvingsopplegget vårt, der nytt stoff vert formidla gjennom oppgåver og døme, er basert (ved sidan av Clark mfl. (2005)) på idéane bak den klassiske læreboka åt Colburn (1822). Han viste, m.a., korleis elevar viser at dei kan rekna både kjapt og korrekt for å løysa kvardagsproblem, sjølv om dei ikkje kan løysa dei same matematiske problema i abstrakt form.

\section{VEGEN FRAMOVER}

Studentane på økonomisk/administrative fag vert sjelden matematikarar. Dei skal læra å forstå, forklara og drøfta økonomiske sider ved røynda. Då er matematikken eit middel og ikkje eit mål. Dette krev modellerings-, kommunikasjons- og tankesettskompetanse, meir enn dei rekneferdigheitene som tradisjonelt vert vurderte på eksamen. Utan å fokusera på desse kompetansane innanfor fagområde og praktiske problem som studentane kan leva seg inn i, gjer me matematikken både unyttig og uoverkommeleg for fleirtalet av studentane.

Det er som om matematikkundervisinga er retta mot studentar som tek sin fyrste jobb som computers, slik mange studentar gjorde på 1940 og -50-talet. Verda ser ut til å ha endra seg meir enn studiet på dei siste 70-80 åra.

Me ser oss tvungne til å revurdera mange etablerte vanar i matematikkundervisinga, og me har starta på ein omlegging frå abstrakte, velformulerte rekneoppgåver, til meir heilskaplege oppgåver frå røynda, der studenten sjølv må matematisera og forma problemet. Ei typisk oppgåve frå kapittelet om geometriske rekkjer kan t.d. vera

Ola har ein sparekonto med 3\% rente. Han set inn 1000 kr. kvart år i tredve år. Kor stor er saldoen når han har sett inn det trettiande beløpet?

Studenten treng ikkje å kunna noko om geometriske rekkjer for å forstå og leva seg inn i problemet. Det er til og med mogleg å løysa heile oppgåva ved å tabulera rentene (med enkel prosentrekning) og saldoen år for år, før ein går inn i nye teknikkar for å løysa oppgåva meir effektivt. Det er eit hovudmål at oppgåva skal vera meiningsfull sett frå dei levde røynslene som studenten har og dei tankane som han gjer seg om framtidig yrke.

Dette skiftet i prioriterte læringsutbyte, gjer matematikken i større grad til eit danningsfag som ein må formidla gjennom modellæring, og i langt mindre grad eit utdanningsfag som kan forklarast (jf. Kemp, 2013, s. 181). Dette fører til at førelesinga etter kvart legg større vekt på å visa heile løysingsprosessen, med idémyldring, prøving og (kanskje spesielt) feiling, for at studentane skal vera vitne til heile tankesettet og ikkje berre til ein ferdig, polert løysingspresentasjon. Dette tyder ikkje at me heilt skal slutta å forklara, og det vil ta tid å finna den rette balansen mellom modellæring og forklaring.

Det har vore eit problem, med $2 \mathrm{~h}$ førelesingsøkter, at studentane får meir forklaring enn dei maktar å skaffa seg røynsler med. Dette vert endå verre når mange studentar i liten grad arbeider med oppgåver og søkjer hjelp når dei treng det. I 2019 vart dette lagt om til to 4h-økter med $1 \mathrm{~h}$ førelesing på starten og på slutten, og $2 \mathrm{~h}$ rekneøving i midten. Denne endringa skal me evaluera meir utførleg i eit seinare arbeid.

Eikor omlegging av læringsmåla i eit fag må vera gjennomførd heile vegen frå undervisinga startar til eksamen er gjennomførd, og vurderingskriteria må vera klart kommuniserte for studentane frå starten av. 
Dersom dette ikkje er tydeleg nok, vil studentane forhalda seg til læringsmål slik dei framstår i eksamenstradisjonen. Når me har gjort dette i praksis, ser me at store studentgrupper får ei ny forståing og interesse for matematikk gjennom problem frå røynda, men det vil ta tid å byggja opp ein eksamenshistorikk som gjer målendringa tydeleg for alle.

Kan me so konkludera om kva målet er for matematikken? Me trur ikkje det. Snarare må kvar og ein søkja etter målet for matematikken innanfor kvart studieprogram og kvar studentgruppe. Matematikken skal tena studentane der dei er, eller dit dei skal, og me må forstå faget i denne konteksta. Dei tidlause rekneteknikkane vil aldri vera eit tilstrekkeleg mål, sidan me i praksis plar overlata dei til maskiner. Nytte av matematikken har ein fyrst når ein kan formulera problem frå røynda slik at maskiner kan løysa resten. Når me ser at grunnleggjande ferdigheitsmål ikkje motiverer studentane til faktisk å læra, og å hugsa, vis slike mål hemma læringa. Motivasjon for matematikk oppstår berre når matematikken får meining i den konteksta der studentane lever, og som lærar må ein setja seg inn i den konteksta før ein set læringsmål.

Til sjuande og sist, må me vedgå at me stadig er langt frå ei fullgod løysing. Det me vonar å bidra til er ei betre problemforståing, slik at me, ved fleire utdanningar, kan vri fokus for matematikkopplæringa over på studenten og deira framtidige bruk av matematikken.

\section{REFERANSAR}

Aristoteles. (1999). Etikk [Omsett av Anfinn Stigen]. Gyldendal Akademisk.

Biggs, J. \& Tang, C. (2011). Teaching for Quality Learning at University (4th). McGraw Hill/Open University Press.

Boaler, J. (1998). Open and closed mathematics: Student experiences and understandings. Journal for research in mathematics education, 29(1), 41-62. https://doi.org/10.5951/jresematheduc.29.1. 0041

Boaler, J. (2015). Mathematical mindsets: unleashing students ' potential through creative math, inspiring messages, and innovative teaching. Jossey-Bass.

Clark, R. C., Nguyen, F. \& Sweller, J. (2005). Efficiency in Learning: Evidence-Based Guidelines to Manage Cognitive Load. Pfeiffer, San Francisco.

Colburn, W. (1822). First lessons in arithmetic on the plan of Pestalozzi: With some improvements (Second). Cummings; Hilliard.

Collins, A. (1992). Toward a design science of education. I E. Scanlon \& T. O'Shea (Red.), New directions in educational technology (s. 15-22). Springer Berlin Heidelberg.

De Bock, D., Deprez, J., Van Dooren, W., Roelens, M. \& Verschaffel, L. (2011). Abstract or concrete examples in learning mathematics? A replication and elaboration of Kaminski, Sloutsky, and Heckler's study. Journal for research in Mathematics Education, 42(2), 109-126. https://doi. org/10.5951/jresematheduc.42.2.0109

Foldnes, N. (2016). The flipped classroom and cooperative learning: Evidence from a randomised experiment. Active Learning in Higher Education, 17(1). https://doi.org/10.1177/1469787415616726

Gadamer, H.-G. (1960). Wahrheit und Methode. Tübingen.

Green, K. \& Emerson, A. (2008). Reorganizing freshman business mathematics II: Authentic assessment in mathematics through professional memos. Teaching Mathematics and its Applications: An International Journal of the IMA, 27(2), 66-80. https://doi.org/10.1093/teamat/hrn002

Hendrix, G. (1947). A new clue to transfer of training. The Elementary School Journal, 197-208.

Hevner, A. R. (2007). A Three Cycle View of Design Science Research. Scandinavian Journal of Information Systems, 19(2), 87-92.

Holm, M. (2012). Opplcering i matematikk. Cappelen Damm.

Kaminski, J. A., Sloutsky, V. M. \& Heckler, A. F. (2008). The Advantage of Abstract Examples in Learning Math. Science, 320(5875), 454-455. https://doi.org/10.1126/science.1154659 
Karlsen, G. (2006). Stilt overfor det som ennå ikke er. I K. Steinsholt \& H. Sommerro (Red.), Improvisasjon. Kunsten å sette seg selv på spill (s. 239-259).

Kemp, P. (2013). Verdensborgeren: pcedagogisk og politisk ideal for det 21. århundrede (2. reviderede udgave). Hans Reitzels Forlag.

Kerdeman, D. (1998). Hermeneutics and education: Understanding, control, and agency. Educational Theory, 48(2), 241-266.

Kloosterman, P. \& Cougan, M. C. (1994). Students' Beliefs about Learning School Mathematics [https: //www.jstor.org/stable/1001944]. The Elementary School Journal, 94(4), 375-388.

Krogstie, B. R., Berntsen, K. E. \& Wrålsen, A. (2018). Adapting team-based learning in a mathematics course for computer engineering students. Norsk konferanse for organisasjoners bruk at IT, 26(1).

Maher, M. \& Tang, H.-H. (2003). Co-evolution as a computational and cognitive model of design. Research in Engineering Design, 14(1), 47-64. https://doi.org/10.1007/s00163-002-0016-y

Niss, M. \& Højgaard, T. (2011). Competencies and Mathematical Learning: Ideas and inspiration for the development of mathematics teaching and learning in Denmark (tekn. rapp.). IMFUFA, Roskilde university.

Norman, D. (2013). The design of everyday things: Revised and expanded edition. Constellation.

Piercey, V. \& Militzer, E. (2017). An inquiry-based quantitative reasoning course for business students. PRIMUS, 27(7), 693-706.

Polanyi, M. (1983). The Tacit Dimension [First published Doubleday \& Co, 1966.]. Peter Smith, Gloucester, Massachussets.

Sawyer, R. K. (2004). Creative teaching: Collaborative discussion as disciplined improvisation. Educational researcher, 33(2), 12-20.

Schön, D. A. (1983). The Reflective Practioner. Ashgate Arena.

Schaathun, H. G. (2015). Matematikk er eit pratefag og andre røynsler frå eit omvendt klasserom [Presentert på Undervising og Didaktikk i IT-faga, Ålesund 23.-25, november 2015. Open tilgang på https://ojs.bibsys.no/index.php/NIK/article/view/255/218.]. Norsk Informatikkonferanse.

Schaathun, H. G. \& Gundersen, S. S. (2018). Quiz for diskusjon og samarbeid i store klasser [Presentert på Undervising og Didaktikk i IT-faga, Svalbard 18.-20. sept. 2015. Open tilgang på https://ojs. bibsys.no/index.php/NIK/article/view/517/441.]. Norsk Informatikkonferanse.

Selden, A., Selden, J., Hauk, S. \& Mason, A. (2000). Why can't calculus students access their knowledge to solve non-routine problems. Issues in mathematics education, 8, 128-153.

Simon, H. A. (1996). The sciences of the artificial (3rd). MIT press.

Sotto, E. (2007). When Teaching Becomes Learning: A Theory and Practice of Teaching (2nd). Continuum.

Yoshinobu, S. \& Jones, M. G. (2012). The coverage issue. Primus, 22(4), 303-316. https://doi.org/10. $1080 / 10511970.2010 .507622$ 